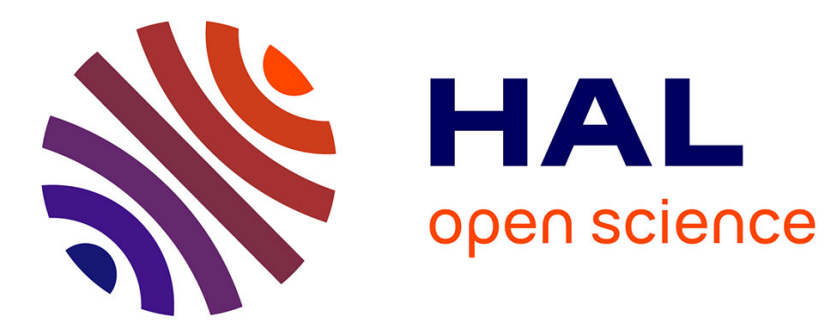

\title{
Loanwords in Sakha (Yakut), a Turkic language of Siberia
}

\author{
Brigitte Pakendorf, Innokentij N Novgorodov
}

\section{To cite this version:}

Brigitte Pakendorf, Innokentij N Novgorodov. Loanwords in Sakha (Yakut), a Turkic language of Siberia. In Martin Haspelmath, Uri Tadmor. Loanwords in the World's Languages: a Comparative Handbook, de Gruyter Mouton, pp.496-524, 2009. hal-02012602

\section{HAL Id: hal-02012602 \\ https://hal.univ-lyon2.fr/hal-02012602}

Submitted on 23 Jul 2020

HAL is a multi-disciplinary open access archive for the deposit and dissemination of scientific research documents, whether they are published or not. The documents may come from teaching and research institutions in France or abroad, or from public or private research centers.
L'archive ouverte pluridisciplinaire HAL, est destinée au dépôt et à la diffusion de documents scientifiques de niveau recherche, publiés ou non, émanant des établissements d'enseignement et de recherche français ou étrangers, des laboratoires publics ou privés. 


\section{Chapter 19}

\section{Loanwords in Sakha (Yakut), a Turkic language of Siberia*} Brigitte Pakendorf and Innokentij N. Novgorodov

\section{The language and its speakers}

Sakha (often referred to as Yakut) is a Turkic language spoken in northeastern Siberia. It is classified as a Northeastern Turkic language together with South Siberian Turkic languages such as Tuvan, Altay, and Khakas. This classification, however, is based primarily on geography, rather than shared linguistic innovations (Schönig 1997: 123; Johanson 1998: 82f); thus, Ščerbak (1994: 37-42) does not include Sakha amongst the South Siberian Turkic languages, but considers it a separate branch of Turkic. The closest relative of Sakha is Dolgan, spoken to the northwest of the Republic of Sakha (Yakutia). In contrast to the Sakha, who are cattle and horse pastoralists, Dolgans are nomadic reindeer herders and hunters. On linguistic grounds Dolgan is sometimes classified as a dialect of Sakha (e.g. Voronkin 1999).

Sakha is spoken by the vast majority of the 443,852 ethnic Sakha living in the Russian Federation, most of whom reside in the autonomous Republic of Sakha (Yakutia). Language retention among the Sakha is high - according to the 2002 population census, approximately $93 \%$ of Sakha know their heritage language, and only approximately $87 \%$ know Russian; among the rural population this figure is even lower, with only approximately $83 \%$ of the Sakha claiming a knowledge of Russian (Federal'naja služba gosudarstvennoj statistiki 2004: 19, 24, 113, 130). Amongst urbanized Sakha knowledge of Russian is more widespread, since in towns Russians and Ukrainians dominate numerically, whereas villages are predominantly monoethnically Sakha. As mentioned, the Sakha are mostly cattle- and horsebreeders who historically followed a pattern of seasonal transhumance, moving from light summer dwellings to very solid winter houses and back.

Sakha is used widely in the home, especially in rural settlements, where children below school age and some older people are monolingual, notwithstanding the fact that often the only television channels that can be received in such settlements are Russian. In the public domain, use of Sakha varies. In rural settlements, business and administration is conducted in Sakha; in towns and "industrial settlements", in

\footnotetext{
The subdatabase of the World Loanword Database that accompanies this chapter is available online at http://wold.livingsources.org. It is a separate electronic publication that should be cited as follows: Pakendorf, Brigitte \& Novgorodov, Innokentij N. 2009. Sakha vocabulary. In Haspelmath, Martin \& Tadmor, Uri (eds.) World Loanword Database. Munich: Max Planck Digital Library, 1411 entries. <http://wold.livingsources.org/ vocabulary/19>
} 
which Europeans from the European part of Russia and the former Soviet Union (mostly Russians and Ukrainians) dominate, Russian is widely used. The language of education varies from school to school, with "national schools" generally offering Sakha as the medium of teaching for all subjects in primary school and up to grade eight, while in "Russian schools" all subjects are taught in Russian from the beginning; furthermore, there may be parallel Russian-language and Sakha-language classes in one and the same school. Throughout the Republic of Sakha (Yakutia) Russian television channels can be received, while the Sakha-language television operating from Yakutsk can generally not be received outside of a fairly small area surrounding Yakutsk. ${ }^{1}$ There is, however, a Sakha-language radio service broadcasting throughout the republic. Furthermore, there are Sakha-language television services operating from different district centres with a weekly programme; the broadcasting range of these, however, often does not extend beyond the centre itself. In addition, there are a number of Sakha-language newspapers and magazines which are widely subscribed to, as well as books appearing in Sakha. In Yakutsk, there exists a Sakha-language theatre which presents plays in Sakha.

There is a general consensus that the Sakha are not indigenous to Yakutia, but immigrated from an area further to the south. This can be seen both from their Turkic language and their subsistence pattern of cattle and horse pastoralism. Archaeologists suggest that the ancestors of the Sakha are the Kurykans known from Chinese chronicles and archaeological finds on the shores of Lake Baykal in South Siberia, whose culture is dated to the $6^{\text {th }}$ to $10^{\text {th }}$ century CE. Judging from runic inscriptions found in conjunction with these archaeological sites, the Kurykans are presumed to have been a Turkic-speaking population (Okladnikov 1955; Śirobokova 1977; Konstantinov [1975] 2003; Gogolev 1993; Alekseev 1996). The main mass of Turkic-speaking Sakha ancestors is taken to have immigrated to the middle reaches of the Lena river in the $13^{\text {th }}$ or $14^{\text {th }}$ century (Gogolev 1993: 61, 88f; Alekseev 1996: 46).

The Republic of Sakha (Yakutia) covers an enormous territory of more than $3,000,000 \mathrm{~km}^{2}$ (Safronov 2000: 11). Although nowadays Sakha are settled over most of this territory, at the time of first Russian contact in the $17^{\text {th }}$ century (the Yakutsk fort was founded in 1632) the Sakha were concentrated mainly in a fairly small area of central Yakutia, between the Lena, Amga and Aldan rivers (Dolgix 1960: 377). Thus, their expansion over the large area they inhabit today occurred quite recently, in the $17^{\text {th }}$ and $18^{\text {th }}$ centuries (Dolgix 1960: 360ff; Forsyth 1992: 63; Wurm 1996: 971f).

\footnotetext{
${ }^{1}$ However, this may have changed recently with the installation of satellite connections in most or even all villages.
} 


\section{Sources of data}

\subsection{The sources of the Sakha lexical items included in the subdatabase}

The primary source of the Sakha data analyzed in this study was direct elicitation from a consultant in Yakutia. This elicitation was undertaken in November 2003 by Pakendorf in the village of Tabalaax in the Verxojansk district and was based on a Russian translation of the IDS wordlist (Ritchie Key \& Comrie, http://lingweb.eva.mpg.de/ids/). The consultant providing the items was Elizaveta Migalkina, a native speaker of Sakha who works as a teacher of Russian; at the time of elicitation Ms Migalkina was 30 years old. Furthermore, Novgorodov elicited the items from the semantic field Modern world from Anna Atlasova, an 80-year-old native speaker of Sakha born in the Namcy district in central Yakutia, for whom Sakha still is the dominant and primary language.

In addition to eliciting data from these consultants, some items were contributed by Novgorodov himself. Furthermore, the Russian-Sakha dictionary (Afanas'ev \& Xaritonov 1968) was consulted for some items. In order to verify the meanings of Sakha words and their usage, we used the Sakha-Russian dictionary (Slepcov 1972) as well as the newly-appearing "Explanatory dictionary of Sakha" (Slepcov 2004, 2005), for which the volumes for words beginning with A and B had appeared when work on the subdatabase was being conducted.

\subsection{Previous work on lexical copies in Sakha}

Since the Sakha language is quite divergent from other Turkic languages, and since the Sakha are known to have been settled amongst speakers of other languages for several centuries, the possible impact of contact on their language has been the topic of much prior work. We were thus able to base our analyses of the words included in the subdatabase on ample foundations.

Our first resource in attempting to etymologize the words obtained for the database was the 1900-page-strong dictionary published by Ėduard Pekarskij from 1907 to 1930 , the data for which was collected in the final decades of the $19^{\text {th }}$ century, when Pekarskij was a political exile living in Yakutia. This excellent source on the Sakha lexicon gives the etymologies of a large number of words and provides possible Mongolic parallels and sources.

A further source we consulted very frequently is the thorough study of the Mongolic copies in Sakha published by Kałużyński (1962). Here, Kałużyński provides a detailed analysis of the copies (both lexical items and morphemes) from Mongolic languages found in Pekarskij's dictionary ([1907-1930] 1958-1959). In addition to his monograph on Mongolic copies, Kałużyński continued to conduct etymological studies of Sakha until the mid-1980s, the majority of which are compiled in the collection of his writings on Sakha, IACUTICA, published in 1995. Since this work has been provided with a comprehensive index of the Sakha lexical 
items discussed in the various articles, it was a much-used source, and for simplicity's sake we cite all of Kałużyński's findings from this compilation (even the data from the 1962 monograph).

Other studies dealing with lexical copies in Sakha are Antonov (1971), Romanova et al. (1975), Rassadin (1980), and Popov (1986). Antonov (1971) discusses the origin of Sakha lexical items divided by lexical domain, and within each domain by source language (Turkic, Mongolic, Evenki). Romanova et al. (1975) highlight the "mutual influence of Evenki and Sakha". While they deal less extensively with the Evenki influence on Sakha than with the Sakha influence on the Evenki dialects spoken in Yakutia, they do provide a list of 35 Evenki lexical copies not restricted to the dialectal lexicon (p. 163-166), with a further, more extensive, list of Evenki lexical copies found in the northwestern and southern dialects of Sakha appended. Finally, Rassadin (1980) discusses the Mongolic copies in Sakha based on Kałużyński's (1962) data, while Popov (1986) analyses words of "unknown origin", i.e. words that preceding researchers had not been able to etymologize.

\subsection{Etymological and other dictionaries}

Fortunately for us, the Turkic languages have been very well studied and a lot is known about the cognates found in these languages. Our predominant source of information on the lexical items which Sakha may have inherited from its Turkic ancestor was the "Etymological dictionary of the Turkic languages" (ESTJ 19742003), for which seven volumes exist (discussing words beginning in a vowel as well as the consonants from B to S). A further source was Räsänen (1969), which is another, much shorter, etymological dictionary provided with a comprehensive index (compiled by István Kecskeméti, 1971), as well as the lexicon part of the "Historical-Comparative Grammar of the Turkic Languages" edited by Tenišev (2001), which is a compilation of cognate lexical items in the Turkic languages arranged thematically.

For the Tungusic languages, there exists the comprehensive "Comparative dictionary of the Tungusic languages" (Cincius 1975, 1977), which also contains information on copied items (both such lexical items that were copied into Sakha from Tungusic, as well as those that were copied from Sakha into Evenki or Even), while for Mongolic we consulted primarily the comprehensive Mongolian-English Dictionary edited by Lessing (1995).

For the analysis of Russian copies in Sakha that were made prior to Sovietization we consulted Pekarskij's dictionary; and for words that were copied during the Soviet era we used the Sakha-Russian (Slepcov 1972) and Russian-Sakha (Afanas'ev \& Xaritonov 1968) dictionaries. For words that may have been copied from Russian dialects spoken in Siberia, Anikin's (2003) dictionary of Russian lexical copies in the indigenous languages of Siberia was a useful source. In order to exclude lexical items restricted to certain dialects of Sakha two dialectological dictionaries (Afanas'ev et al. 1976, Voronkin et al. 1995) were consulted. 


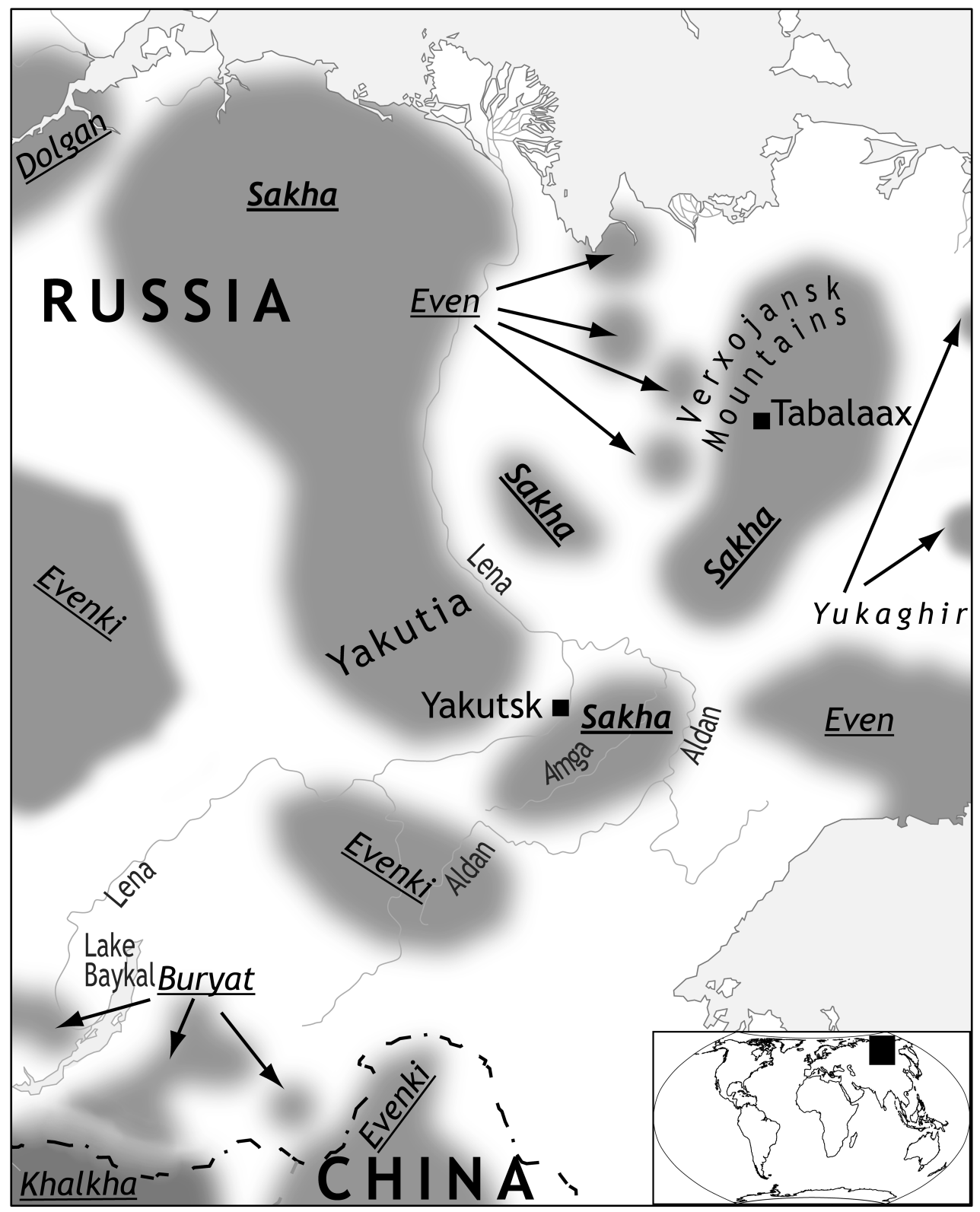

Map 1: Geographical setting of Sakha

\section{Contact situations}

In the following we provide some brief information on the kinds of language contact situations in which Sakha itself was involved. A few words included in the 
subdatabase that are marked as "probably" or "clearly copied", are words that are assumed to have been copied into Proto-Turkic from a variety of languages. These ancient copies are not of interest from a perspective of the contact that the speakers of Sakha were involved in, since in Sakha these items were probably retained from the ancestral language. Thus, nothing will be said here about the situations that may have led to these copies.

The Sakha or their immediate ancestors were in contact predominantly with speakers of Mongolic, with Evenks, and with Russians. The contact with Russians can be divided into two periods that are characterized by different sociocultural settings: (i) from the first appearance of Russians on the Lena river in 1632 to the 1920s, when Yakutia was included into Bolshevik Russia, and (ii) the Soviet period. Each of these contact situations will be described below.

\subsection{Sakha-Mongolic contact}

Modern-day Mongolic languages are very closely related, stemming from a single ancestor language (called Middle Mongolian) that arose during the unification of the Mongolic tribes under Chinggis Khan at the turn of the $12^{\text {th }}$ and $13^{\text {th }}$ centuries (Janhunen 1998: 203). After the unification by Chinggis Khan, the diversification of Mongolic languages probably took place from the end of the $14^{\text {th }}$ century to the middle of the $16^{\text {th }}$ century (Weiers 1986: 37). A major split exists between the West Mongolic languages Oirat and Kalmyk, and East Mongolic languages, which in turn are divided into three branches: South Mongol, Central Mongol (including Khalkha) and Northern Mongol (or Buryat). Written Mongolian is a language of written communication which was in use amongst different Mongolic-speaking tribes from the $13^{\text {th }}$ century onwards. Amongst the East Mongolic languages it was in use until the $20^{\text {th }}$ century (and still is in use in Inner Mongolia), while the West Mongolic languages Oirat and Kalmyk developed their own script in the $17^{\text {th }}$ century (Weiers 1986: 42).

During the Mongol Empire (1206-1357/1380) the Mongol hordes ruled over huge tracts of Siberia and Central Asia, up to Europe. At that time the ancestors of the Sakha were most likely still settled near Lake Baykal, i.e. in the immediate vicinity of the ruling Mongols. Although there are no historical accounts of the contact between Sakha and Mongolic tribes, the Sakha lexicon shows ample evidence of quite intense contact. Thus, from his analysis of the Mongolic copies in Sakha, Kałużyński comes to the conclusion that the contact took place during the Mongol Empire and the immediately subsequent period, between the $12^{\text {th }} / 13^{\text {th }}$ and the $15^{\text {th }} / 16^{\text {th }}$ centuries. This is corroborated to a certain degree by genetic data (cf. $\S 7)$. Judging from the nature of the lexical copies, Kałużyński concludes that the Sakha must have been integrated into the Mongol Empire, and that they were socially and politically subordinate to the Mongols. Finally, as it is impossible to trace all substance copies in Sakha to a single Mongolic language, he concludes that the Mongolic source language either does not exist anymore, or that the language 
contact took place over such an extended period of time that speakers of Sakha were in contact with speakers of several different Mongolic dialects (Kałużnński [1962] 1995: 154f, 162). However, an alternative explanation for this lack of correspondence between the Mongolic copies in Sakha and any one individual presentday Mongolic language is the fact that during the unification of the Mongolic tribes into one empire, Chinggis Khan unified the dialects into one language (Janhunen 1998: 203), as mentioned above. Thus, it is possible that the Mongolic language with which the ancestors of the Sakha were in contact only later split into the varieties found today. For this reason, in the subdatabase the model language is given as "Mongolic" rather than any one specific language, with the exception of those cases where the lexical copy has a correspondence in only one Mongolic language (e.g. Kalmyk, Buryat, or Khalkha).

\subsection{Contact with indigenous northern Siberian peoples}

The contact in which the Sakha and the Tungusic-speaking Evenks were involved is rather enigmatic. When the Russians first came to Yakutia in the first half of the $17^{\text {th }}$ century, the Sakha were settled in a relatively small territory surrounded by Tungusic-speaking groups, making contact between them plausible. Furthermore, a number of ethnographers mention the intermarriage of the Sakha people with indigenous north Siberian groups as well as the linguistic assimilation of the latter in the centuries between Russian colonization and the advent of the Soviet era (e.g. Seroševskij [1896] 1993: 230f; Dolgix 1960: 461, 486; Tugolukov 1985: 220). Although the Northern Tungusic groups (Evenks and Evens) migrated to the north from Southern Siberia not much earlier than the ancestors of the Sakha, we assume that the Evenki copies detectable in modern-day Sakha entered the language after the ancestors of the Sakha migrated to the north. Thus, this contact situation is characterized by newcomers in need of words to describe the fauna and flora they encounter in their new area of settlement, and this is reflected in the Evenki lexical copies found in Sakha.

However, the social type of contact is very hard to elucidate: on the one hand, there is no genetic evidence for large-scale intermarriage between Sakha and Evenks, although some female admixture between them cannot be ruled out (Pakendorf et al. 2006; cf. §7). On the other hand, there is evidence of Evenki influence in structural domains (i.e. schematic rather than substance copies), indicating some fairly intense linguistic contact on the part of the Sakha ancestors. This implies that the ancestors of the Sakha were bilingual in Evenki without concomitant large-scale intermarriage with them (Pakendorf 2007: 303-323). There is genetic evidence of a very strong bottleneck in the paternal prehistory of the Sakha (cf. §7), indicating that a very small group of probably related men migrated to the north. This small group may have been dependent on their indigenous neighbors in the early period after their migration, when their cattle and horse herds were still fairly vulnerable in the harsher northern climate. At a later stage, however, after 
Russian contact, the Sakha quickly became the numerically and socially dominant indigenous group in the area.

In addition to the known physical contact between Sakha and Evenks, in the northeastern region of their settlement the Sakha are in contact with two more indigenous Siberian groups, the Evens (who speak a Northern Tungusic language related to Evenki) and the Yukaghirs (who speak an isolated language at best distantly related to Uralic). However, this contact has not had any noticeable impact on the Sakha lexicon. Thus, no lexical copies of Yukaghir origin are found in the general Sakha lexicon, and only four such copies can be found in Sakha dialects. Similarly, the impact of Even copies is minimal. Although some of the items which we classified as having been copied from Evenki are also found in Even and might thus have been copied either from Even or Evenki, others can be traced only to Evenki, making this language the more probable model for all the Northern Tungusic lexical copies in Sakha.

\subsection{Sakha-Russian contact - the pre-Soviet period}

As mentioned, Russians first reached the Lena river in 1632, when they established a fort on its right bank. In the early period of Russian colonization, Russia's main interest was to extract as many furs as possible, which were collected by contingents of cossacks and fur traders from the European part of Russia. However, only a small number of Russians lived in Yakutia until the middle of the $20^{\text {th }}$ century (Forsyth 1992: 61, 190, 253) and in the early years contact with speakers of Russian was certainly minimal. Later on, the number of Russians in Yakutia increased, when more traders, missionaries and government officials arrived. Furthermore, beginning in the $18^{\text {th }}$ century large numbers of political exiles from the European part of the Russian Empire were sent to Yakutia (Forsyth 1992: 193-195). In this period, contact between the Sakha and speakers of Russian may have been somewhat more intense, because a larger number of Russians lived in Yakutia. However, even in 1917, Russians only constituted $10.5 \%$ of the total number of inhabitants of Yakutia (Forsyth 1992: 253). Furthermore, in this period a number of Russians living in Yakutia spoke Sakha, which became the lingua franca of the region (Forsyth 1992: 165; Maslova \& Vaxtin 1996), thereby limiting the amount of contact of Sakha speakers with the Russian language. Thus, during this time period the contact was mainly cultural, with the importation of a number of previously unknown items (bread, tobacco, firearms, vodka, books, etc) and concepts (such as the Christian religion) together with the names for them.

\subsection{Sakha-Russian contact - the Soviet period}

The Bolsheviks established rule over Yakutia in 1922 (Forsyth 1992: 258), and as is well known, the Soviet Union existed until 1991. In the early years of this period, 
literacy in Sakha was promoted through the development of an alphabet and publications in the language. Later, however, large-scale Russianization took place, with the mass media and schooling being predominantly in Russian. Furthermore, industrialization in certain parts of Yakutia led to an influx of workers from the European part of the Soviet Union (predominantly Russia and the Ukraine; Forsyth 1992: 286, 361, 379f). This development was at its height during the latter half of the $20^{\text {th }}$ century, when it was forbidden to speak Sakha in Yakutsk, and village meetings had to be held in Russian if only one European was present (cf. Forsyth 1992: 407). Nevertheless, as described in $§ 1$, Sakha remained the dominant language in rural villages, with pre-school children and even older people being monolingual. During this time period, a further large number of modern cultural items (tractors, cars, radios, television sets, telephones, etc.) were introduced into Yakutia together with their Russian names.

\section{Numbers and kinds of lexical copies}

\subsection{General observations}

The subdatabase for Sakha includes 1411 Sakha words. Of the 1460 different meanings on the Loanword Typology meaning list, 161 have no corresponding Sakha word form; 128 of these are meanings irrelevant to speakers of Sakha (dealing predominantly with tropical flora and fauna), and 33 have no counterpart in the language (for example, terms for siblings not differentiated by relative age, or the verbs 'to have' and 'to own'). With regard to synonyms, 221 of the LWT meanings have two Sakha counterparts, 26 have three counterparts, four have four counterparts and one ('the pot') has five counterparts. As regards polysemies, 112 Sakha words correspond to two Loanword Typology meanings, 22 words correspond to three meanings, and seven words correspond to four meanings, e.g. et 'body, flesh, carcass, meat'.

Of the 1411 Sakha words included in the subdatabase, 409 (approximately 29\%) were classified as "probably" or "clearly copied" (cf. Appendix). Three of these were copied at the stage of Proto-Turkic and were most probably retained in Sakha from the ancestral language; these are oyus 'ox', which is assumed to have been copied from Proto-Indo-European (ESTJ 1974: 522); seri: 'war, armed forces' copied from Sanskrit (Ščerbak 1994: 122); and ti:t 'larch' copied from Finno-Ugric (Räsänen 1969: 479a). In addition, the Sakha word for 'sword', bolot, has its ultimate model in Persian (Kałużnński 1995 [1962]: 157); however, it is not known exactly when and how this entered Sakha, though Mongolic mediation is likely (Ščerbak 1994: 123). Thus, 405 items can be assumed to have been copied into Sakha (or its immediate ancestor) as such.

There are several words that begin with an $s$ - in Sakha, the Turkic cognates of which also begin with an $s^{-}$(sitim 'thread' in o: zuy sitime 'spiderweb', sil 'spittle' in sille: 'to spit', si: $k$ 'nasal mucus', sap 'thread', subuox 'plait, braid', sayas (the archaic 


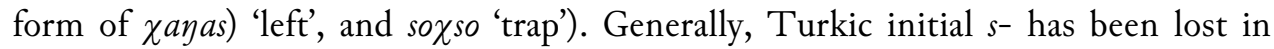
Sakha (Johanson 1998: 103), so that these items may represent copies from some Turkic language into Sakha after the loss of initial $s$ - had taken place.

Not surprisingly, the vast majority (336 or $82 \%$ ) of the 409 copies are nouns (cf. Table 1); 44 (i.e. 10.8\%) are verbs, which were predominantly copied from Mongolic languages (cf. §4.3), while only four verbs were copied from Russian and one verb was copied from Evenki. Twenty-one of the copies (approximately 5\%) are adjectives, and eight (2\%) are function words (the quantifiers 'many' and 'enough', the numerals 'zero' and 'thousand', three polysemous synonyms for 'always, often', and the adverb 'late'). As shown by Table 2, $40 \%$ of the Sakha nouns have a foreign origin, as do approximately $16 \%$ of the adjectives and nearly $13 \%$ of the verbs; while adverbs classified as such in the subdatabase have not been copied.

Table 1:

Lexical copies by model language and semantic word class (absolute numbers)

\begin{tabular}{lrrrrrr}
\hline \hline & Russian & Mongolic & Evenki & Other & Total copies & Not copied \\
\hline Nouns & 230 & 87 & 13 & 6 & 336 & 505 \\
Verbs & 4 & 39 & 1 & - & 44 & 299 \\
Adjectives & 3 & 18 & - & - & 21 & 109 \\
Adverbs & - & - & - & - & - & 4 \\
Function words & 3 & 4 & - & 1 & 8 & 85 \\
\hline all words & $\mathbf{2 4 0}$ & $\mathbf{1 4 8}$ & $\mathbf{1 4}$ & $\mathbf{7}$ & $\mathbf{4 0 9}$ & $\mathbf{1 0 0 2}$ \\
\hline \hline
\end{tabular}

Table 2:Lexical copies by model language and semantic word class (percentages)

\begin{tabular}{lrrrrrr}
\hline \hline & Russian & Mongolic & Evenki & Other & Total copies & Not copied \\
\hline Nouns & 27.3 & 10.3 & 1.5 & 0.7 & 40.0 & 60.0 \\
Verbs & 1.2 & 11.4 & 0.3 & - & 12.8 & 87.2 \\
Adjectives & 2.3 & 13.8 & - & - & 16.2 & 83.8 \\
Adverbs & - & - & - & - & 0.0 & 100.0 \\
Function words & 3.2 & 4.3 & - & 1.1 & 8.6 & 91.4 \\
\hline all words & $\mathbf{1 7 . 0}$ & $\mathbf{1 0 . 5}$ & $\mathbf{1 . 0}$ & $\mathbf{0 . 5}$ & $\mathbf{2 9 . 0}$ & $\mathbf{7 1 . 0}$ \\
\hline \hline
\end{tabular}

Lexical copies are found in practically every semantic field, with the exception of the field Miscellaneous function words (cf. Table 3). Table 4 shows the fields ranked by proportion of copied items; the five fields with the largest proportion of copies are (in descending order): Modern world, The bouse, Agriculture and vegetation, Food and drink, and Clothing and grooming. In all of these fields, it is the words denoting western-style items that were copied, mainly from Russian. The five fields with the lowest proportion of copies are (in ascending order): Miscellaneous function words (with no copies), Sense perception, Kinship, Spatial relations, and The body. However, although the proportion of copies in the field The body is relatively low, it is still 
interesting that 24 body part terms were copied, 19 of these from Mongolic languages.

Table 3: Lexical copies by model language and semantic field (percentages)

\begin{tabular}{|c|c|c|c|c|c|c|c|}
\hline & & 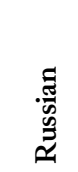 & $\begin{array}{l}\stackrel{.}{\circ} \\
0 \\
\stackrel{0}{0} \\
\dot{0}\end{array}$ & 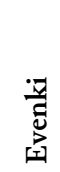 & 壱 & 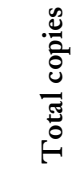 & 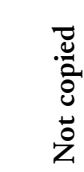 \\
\hline & The physical world & 9.9 & 11.3 & 4.2 & 0.7 & 26.2 & 73.8 \\
\hline & Kinship & 6.0 & 11.4 & - & - & 17.4 & 82.6 \\
\hline & Animals & 15.9 & 11.4 & 3.4 & 1.1 & 31.8 & 68.2 \\
\hline & The body & 2.4 & 11.5 & 0.6 & - & 14.5 & 85.5 \\
\hline & Food and drink & 38.9 & 4.9 & - & - & 43.9 & 56.1 \\
\hline 6 & Clothing and grooming & 41.5 & - & 1.6 & - & 43.1 & 56.9 \\
\hline & The house & 42.6 & 16.6 & 2.1 & - & 61.2 & 38.8 \\
\hline & Agriculture and vegetation & 28.2 & 12.3 & 3.5 & 2.7 & 46.6 & 53.4 \\
\hline & Basic actions and technology & 9.8 & 15.5 & 1.4 & - & 26.7 & 73.3 \\
\hline & Motion & 13.4 & 11.5 & - & 1.3 & 26.1 & 73.9 \\
\hline & Possession & 16.5 & 16.1 & - & - & 32.7 & 67.3 \\
\hline & Spatial relations & 1.3 & 12.6 & - & - & 13.9 & 86.1 \\
\hline & Quantity & 11.2 & 5.2 & - & - & 16.4 & 83.6 \\
\hline & Time & 18.5 & 11.8 & - & 1.7 & 31.9 & 68.1 \\
\hline & Sense perception & - & 4.5 & - & - & 4.5 & 95.5 \\
\hline & Emotions and values & 3.3 & 15.7 & 1.7 & - & 20.7 & 79.3 \\
\hline & Cognition & 9.5 & 14.9 & - & - & 24.4 & 75.6 \\
\hline & Speech and language & 9.7 & 7.3 & - & - & 17.0 & 83.0 \\
\hline & Social and political relations & 12.6 & 12.6 & - & - & 25.2 & 74.8 \\
\hline & Warfare and hunting & 16.2 & 10.8 & - & 5.4 & 32.4 & 67.6 \\
\hline & Law & 17.3 & 17.3 & - & - & 34.7 & 65.3 \\
\hline & Religion and belief & 13.6 & 9.1 & 4.5 & - & 27.3 & 72.7 \\
\hline & Modern world & 83.4 & 0.9 & - & - & 84.3 & 15.7 \\
\hline & Miscellaneous function words & - & - & - & - & - & 100.0 \\
\hline & all words & 17.0 & 10.5 & 1.0 & 0.5 & 29.0 & 71.0 \\
\hline
\end{tabular}

It is noticeable that copies from Mongolic (cf. 1a) have undergone semantic shifts more frequently than copies from Russian. The latter have most often retained the meaning of the Russian model, with a few exceptions (cf. 1b). This may be due to the longer period of time which has passed since the Mongolic copies entered the Sakha language, and also to the fact that the copies from Russian denote predominantly concrete items, while the Mongolic copies often denote qualities or abstract concepts. 
Table 4: Semantic fields ranked by proportion of copies ${ }^{2}$

\begin{tabular}{|c|c|c|c|}
\hline Semantic field & Words in field & Copies & Proportion of copies \\
\hline 23 Modern world & 60 & 47.50 & $79.2 \%$ \\
\hline 7 The house & 53 & 29.50 & $55.7 \%$ \\
\hline 8 Agriculture and vegetation & 64 & 26.50 & $41.4 \%$ \\
\hline 5 Food and drink & 91 & 35.50 & $39.0 \%$ \\
\hline 6 Clothing and grooming & 70 & 26.50 & $37.9 \%$ \\
\hline 21 Law & 26 & 8.00 & $30.8 \%$ \\
\hline 20 Warfare and hunting & 39 & 12.00 & $30.8 \%$ \\
\hline 3 Animals & 91 & 28.00 & $30.8 \%$ \\
\hline 14 Time & 66 & 19.00 & $28.8 \%$ \\
\hline 11 Possession & 53 & 13.83 & $26.1 \%$ \\
\hline 22 Religion and belief & 23 & 6.00 & $26.1 \%$ \\
\hline 9 Basic actions and technology & 83 & 19.00 & $22.9 \%$ \\
\hline 19 Social and political relations & 44 & 10.00 & $22.7 \%$ \\
\hline 10 Motion & 92 & 20.50 & $22.3 \%$ \\
\hline 1 The physical world & 83 & 18.50 & $22.3 \%$ \\
\hline 17 Cognition & 59 & 12.83 & $21.7 \%$ \\
\hline 16 Emotions and values & 64 & 12.50 & $19.5 \%$ \\
\hline 18 Speech and language & 44 & 7.00 & $15.9 \%$ \\
\hline 13 Quantity & 48 & 7.33 & $15.3 \%$ \\
\hline 4 The body & 183 & 24.00 & $13.1 \%$ \\
\hline 12 Spatial relations & 87 & 11.00 & $12.6 \%$ \\
\hline 2 Kinship & 93 & 11.67 & $12.5 \%$ \\
\hline 15 Sense perception & 59 & 2.33 & $3.9 \%$ \\
\hline 24 Miscellaneous function words & 13 & & $0.0 \%$ \\
\hline
\end{tabular}

(1) a. Mongolic taraxay 'scattered, dispersed, spread, disseminated' eri, ere 'to seek, look for, search; beg, request' mal 'domestic animal, livestock, cattle' büri 'completely, entirely, wholely, fully'

\section{Sakha}

tarayay 'bald'

eren 'to hope'

mal 'thing'

büre 'ugly'

\section{b. Russian}

britva 'razor'

ključ 'key'

krug 'circle'
Sakha

biri:ppe 'knife used at table'

külü:s 'lock, padlock'

kuru:k 'always, often'

${ }^{2}$ In this table, the number of words in each chapter includes all the synonyms as well as all polysemous words. Thus, the total number of words in this calculation is 1588 and not 1411, which means that the proportion of copies in each chapter may actually be slightly higher than the number given here. However, the overall ranking should not be greatly affected by this. 
In general, Sakha speakers tend to copy words denoting new items or concepts rather than coining new terms out of old material. Only in a few cases was the meaning of an existing word extended to encompass a new meaning, as exemplified in (2). Furthermore, several calques from Russian can be distinguished, as demonstrated in (3).

$\begin{array}{ll}\text { uot } & \text { 'fire, light' }>\text { 'electricity' } \\ \text { is } & \text { 'to scatter' }>\text { 'to sow' } \\ \text { sis } & \text { 'to hit' }>\text { 'to thresh' } \\ \text { tart } & \text { 'to pull' }>\text { 'to grind grain' } \\ \text { sa: } & \text { 'the bow' }>\text { 'the gun' } \\ a: X & \text { 'to count' }>\text { 'to read' }\end{array}$

(3)

$\begin{array}{llll}\begin{array}{l}\text { Sakha } \\ \text { ebiet kennitten } \\ \text { lunch after }\end{array} & \begin{array}{l}\text { Rosle obeda } \\ \text { after lunch.GEN }\end{array} & \text { 'afternoon' } \\ \begin{array}{l}\text { mas arí:-ta } \\ \text { tree butter-POss.3sG }\end{array} & \begin{array}{l}\text { rastitel'noe maslo } \\ \text { plant } \quad \text { butter }\end{array} & \text { '(vegetable) oil' } \\ \begin{array}{l}\text { eder kibi } \\ \text { young man }\end{array} & \begin{array}{l}\text { molodoj čelovek } \\ \text { young man }\end{array} & \text { 'young man' } \\ \end{array}$

\subsection{Copies from Siberian languages}

One item was probably copied into Sakha from Ket (tiz: 'boat'), and one item was probably copied from Selkup (meldzi 'often, always'); however, it is not at all clear exactly how, when or where these items entered the Sakha language. Fourteen items (1\%) were probably or clearly copied from Northern Tungusic languages. Seven of these are clearly copied only from Evenki, because the Even word is different; five could have been copied from either Evenki or Even, because the model word is identical in the two languages; and two more words have similar cognates in Even and Evenki, but the Sakha form is closer to the Evenki form: Sakha lapča:n

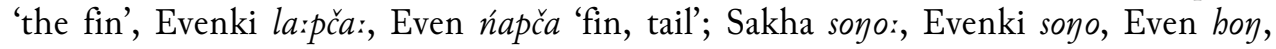
soy 'to cry'. We classified all of these items as having been copied from Evenki for three reasons: (i) More copies (including less certain copies not discussed here) can be traced only to Evenki and not to Even. (ii) Contact with Evenks was more widespread than with Evens, who are settled to the northeast of the Sakha. (iii) Influence on Sakha grammatical structure can be traced to Evenki rather than Even (cf. §6).

The copies from Evenki predominantly come from the domain of natural phe-

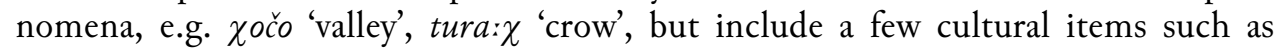
mamikta 'lasso' or untu: 'fur boots'. Only one verb was copied from Evenki (sono: 'to cry, weep'), and so was one body part term: tima 'the lung'. Furthermore, the 
word mas 'wood, tree, firewood, tree trunk' is probably copied; however, the model language is uncertain. It has been suggested as being a copy from Mongolic $\operatorname{modu}(n)$ 'tree' as well as from Evenki mo: 'tree' (Kałużyński 1995 [1962]: 205; Stachowski 1995).

\subsection{Copies from Mongolic}

A very large number of probable or clear copies (148, i.e. approximately 11\%) are from Mongolic languages; amongst these, one can be traced only to Khalkha, three have only Buryat cognates, and one is clearly comparable only to a Kalmyk model (cf. Appendix). However, this number does not accurately reflect the degree of copying that speakers of Sakha undertook from Mongolic, since a number of items in the Loanword Typology meaning list are derived in Sakha from items copied from Mongolic and are so not included in this count. Thus, 29 items are verbs or nouns derived from lexemes probably or clearly copied from Mongolic, or are compounds containing Mongolic copies. Following the guidelines of the Loanword Typology project, these were not classified as copies, since they were derived in Sakha and so represent Sakha innovations. Furthermore, seven items were classified by us as "perhaps copied" not because there are any doubts about the ultimately copied origin of the word, but because they might have either been copied directly from Mongolic (in which case they would have been classified as 'clearly copied'), or they might have been derived from a copied word (in which case they would have been classified as showing 'no evidence of copying'). These items are oyu:r 'the woods or forest', sime $\chi$ 'the ornament or adornment', soruk 'the intention', seberge: 'to tell', mayan 'white', ïges 'the custom', and andayay 'to swear'. If we add these 36 items to the count of Mongolic copies in Sakha, we find a total of 184 (13\%) Mongolic copies in Sakha.

The Mongolic copies come from a wide variety of semantic domains: natural phenomena, kinship terms, body part terms, terms for tools and household items, as well as words describing more abstract concepts such as form and size, time, and thoughts and ideas. However, in the semantic field Food and drink only four copies are from Mongolic, three of them verbs; and no words dealing with clothing were copied from Mongolic. It is furthermore notable that 53 verbs are copied from Mongolic languages (38 of these were classified as "probably" or "clearly copied", while 15 were the basis of derivation of a nominal or different verb included in the Loanword Typology meaning list), i.e. more than one fourth of the Mongolic copies are verbs. This unexpectedly high number might be explained by the similar agglutinative structure of Mongolic and Sakha, and especially by the fact that in both languages the bare stem of the verb functions as a categorical imperative, making verb stems easy to recognize and easy to integrate into the recipient language. 


\subsection{Copies from Russian}

The largest number of copies in Sakha are from Russian: 240 items (17\%) are clearly copied, one further word might be copied ( $\chi$ arči 'money' which formally appears to be copied from dialectal Russian $x a r c ̌ i ~ ' f o o d$ ', although the semantic shift is hard to explain), and three Russian copies appear in compounds. Furthermore, 11 Sakha verbs are derived from copied Russian nouns, and 14 expressions may be calques from Russian. Thus, if one includes all the copies from Russian found in the subdatabase (excluding, however, the calques), there are 255 copies (approximately 18\%) from Russian. Not surprisingly, most of these are connected with items that were introduced through Russian contact, such as bi:lke 'the fork', ki:ne 'the film/movie', or massi:na 'the car'. However, there are some interesting cases concerning words for human relationships, such as the loanblend mača a iỹe 'stepmother', a compound of the Russian word mačexa 'stepmother' and the Sakha word iy ye 'mother'. This is nowadays restricted to stepmothers; previously, however, the compound also occurred with the Sakha word for 'father' aya and then denoted a stepfather. The Russian word for widow vdova was copied into Sakha as ogdo:bo with a meaning of both 'widow' and 'widower'; probably this copy was made because the Sakha word tula:yax 'orphan' used to have a meaning of both 'orphan' and 'widow(er)', so that the copied word served to make a distinction between the kinds of bereft family members. The Russian word brat 'brother' was initially copied with a general meaning of 'brother, sister' without the specification of relative age; nowadays, however, it has acquired a meaning specifically of 'younger brother' and is replacing the indigenous Sakha terms ini 'younger brother of a boy' and surus 'younger brother of a girl'.

\subsection{Synonyms}

A number of copied words are synonymous with other words. In most cases (over 70) they are synonymous with what appear to be inherited words, while in nearly 40 cases synonymous items were copied from different languages, or even from the same language. Copies from Russian often denote the specifically western-style item that was introduced through contact, in contrast with Sakha words that denote the traditional Sakha items, e.g. sele:ppe '(Russian-style) hat', which coexists with bergebe '(Sakha-style fur) hat', or ustu:l 'chair (with back)' vs. oloppos 'stool, Sakhastyle chair'. Interestingly, however, the Russian copy kömülüök is used to designate the traditional open fireplace of the Sakha, while the inherited Turkic word obox designates the Russian-style brick or iron stoves and even modern electric stoves used for cooking.

Although in some cases there are slight differences in meaning between the Turkic word and the Mongolic copy (e.g. copied oyu: $r$ 'forest near the village' vs. inherited tia 'forest further away', or copied öbügeler 'ancestors' vs. törütter 'roots, ancestors'), a number of copies from Mongolic appear to be direct synonyms, such 
as copied soyuo vs. inherited ur 'goitre', copied čöyöčök vs. inherited töyürges 'tree

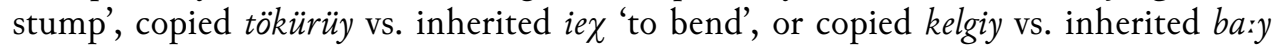
'to tie'. These items may have been copied due to the higher social status the Mongols had during the Mongol Empire, when an apparent knowledge of Mongolic may have conferred some prestige on Sakha speakers.

A number of synonyms were copied first from Mongolic and then again from Russian, or from Russian in pre-Soviet times and then later in Soviet times. For example, the following synonymous pairs were copied first from Mongolic and later from Russian: kieli, matka 'womb'; sülübün, dza:t 'poison', tiergen, telgebe (both from Mongolic), olbuor 'yard', kem, birieme 'time', na:r, kuru:k (as well as meldzi copied from Selkup) 'often, always', kere, kirabiabay 'beautiful', dzenke, čuolkay 'clear', soruk, sial 'intention', and zoruy, eppiet 'the answer' (included in the subdatabase in the derived verbs $\chi$ oruyda: eppiette: 'to answer'). Items copied from Russian during preSoviet times and later from Russian in Soviet times include xortuopuy, xortuoska

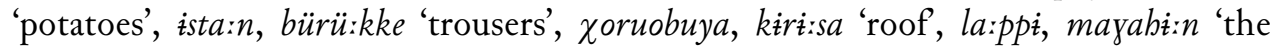
shop', and deriebine, böbüölek 'the village'. Interestingly, three different words for 'the temples' (čečegey, čančžk, and čabiryay) were copied from Mongolic, as well as two different words each for 'to damage' (aldzan, ültürüy) and 'to rescue' (örübüy, abira:), for 'the witness' (tuobu, kerehit) and 'the magic' (ap, xomubun). Whether this might be an indication that the ancestors of the Sakha were in contact with speakers of different Mongolic dialects is unclear; models for all of these words are found in Written Mongolian.

\section{Integration of lexical copies}

\subsection{Phonological integration}

Copies from Mongolic and older copies from Russian are adapted to Sakha phonology, while modern copies from Russian retain their Russian form in Sakha speech, at least by speakers who are fluent in Russian; e.g. Russian avtobus, Sakha avtobus 'the bus'. Some older Sakha speakers, however, who are still monolingual in Sakha, may adapt these items phonologically, such as otuobus 'the bus'. Vowels are changed to follow Sakha vowel harmony rules, e.g.

(4) a. Mongolic

čofčay 'to rise, to loom; to squat' doyulay

b. Russian

kartoška

tarelka

\section{Sakha}

čoxcoy 'to crouch'

doyoloy 'lame'

Sakha

zortuoska 'potatoes'

terielke 'plate' 


\section{Brigitte Pakendorf and Innokentij N. Novgorodov}

Consonant clusters in Russian are broken up through prothetic or epenthetic vowels (5), and stressed syllables in Russian are copied with a long vowel or diphthong in Sakha (6). The Russian labial fricatives $f$ and $v$, which do not exist in native Sakha words, are replaced by the stops $p$ and $b(7)$. Word-initial $p$ and $g$ are missing in Sakha, so that in copies of Russian words these consonants are changed to their counterparts $b$ and $k$ or $\chi$, respectively (8).

\section{Russian Sakha}

$(5)$

$\begin{array}{lll}\text { spička } & \text { ispisse } & \text { 'matches' } \\ \text { svad'ba } & \text { siba:yba } & \text { 'wedding' } \\ \text { vrač } & \text { bira:s } & \text { 'doctor' }\end{array}$

(6) kraska kira:ska 'the paint'

xleb kiliep 'bread'

vremja 'birieme 'time'

(7) konfeta kempiet 'chocolate, sweet'

velosiped belasiped 'bicycle'

vybor bi:bar 'election'3

(8) pyl' bi:l 'dust'

$\begin{array}{lll}\text { posëlok } & \text { böbüölek } & \text { 'settlement, village' } \\ \text { gorod } & \text { kuorat } & \text { 'town' } \\ \text { grabli } & \text { kira:bïl } & \text { 'rake' } \\ \text { gazeta } & \text { xabiat } & \text { 'newspaper' }\end{array}$

In copies from Mongolic that contain sequences of vowel-voiced velar-vowel, the velar consonant $(g$ or $\gamma)$ is lost and the vowels undergo diphthongization or lengthening (Kałużyński [1962] 1995: 55-63), e.g.:

$(9)$

$\begin{array}{lll}\text { Mongolic } & \text { Sakha } & \\ \text { kögemey } & \text { küömey } & \text { 'throat' } \\ \text { kegeli } & \text { kieli } & \text { 'womb' } \\ \text { xadayasun 'nail, peg, spike' } & \text { xata:bin } & \text { 'latch, door-bolt' } \\ \text { sanaya } & \text { sana: } & \text { 'thought' }\end{array}$

${ }^{3}$ Actually, the Russian word vybor means 'choice'; 'election' is the plural form of this, vybory. 


\subsection{Morphological integration}

Lexical copies in Sakha are morphologically well integrated in that they can take the same derivational and inflectional suffixes as native words. Thus, a large number of Sakha adjectives and verbs are derived from nouns copied from Mongolic or Russian; for example kergennen 'to marry (from a man's perspective)' is derived from the noun kergen 'spouse', which was copied from Mongolic, while čeyde: 'to drink tea' is derived from čey 'the tea', which was copied from Russian.

Copies of Mongolic verbs ending in a vowel are occasionally adopted without any further changes (10a), but more often they take a final glide (for the intransitive form), e.g. (10b). Russian verbs, on the other hand, are mostly copied from the imperative form and integrated with the help of the most frequent Sakha verbalizing suffix -la: (and its variants) e.g. (10c). The Russian word prostit' 'to forgive', however, is integrated not with the verbalizing suffix, but with the help of the auxiliary gin 'to do', i.e. Sakha birastit: gin.

$\begin{array}{lll}\begin{array}{l}\text { a. Mongolic } \\ \text { abura 'save, rescue; help, protect' } \\ \text { tölü 'compensate, pay off }\end{array} & \begin{array}{l}\text { Sakha } \\ \text { abira: } \\ \text { tölö: }\end{array} & \begin{array}{l}\text { 'to rescue' } \\ \text { 'to pay' }\end{array} \\ \begin{array}{l}\text { b. daba 'climb, ascend' } \\ \text { ergi 'to turn' }\end{array} & \begin{array}{l}\text { ergiy } \\ \text { 'to go up (a mountain)' }\end{array} & \text { 'to turn' } \\ \text { c. Russian } & \text { Sakha } & \\ \text { mešat' mešaj 'disturb.IMP' } & \text { mehey-de: } & \text { 'to disturb, bother' }\end{array}$

Some copies of plural forms in Russian are treated as non-plural forms in Sakha, such as Russian cvetki 'flowers', Sakha sibekki 'flower(s)', which can take the plural suffix -ler, or Russian grabli 'the rake' (which is morphologically plural), which in Sakha appears in the non-plural form kira:bil.

\section{Grammatical copying}

Although Russian is the model language for most of the lexical copies found in the subdatabase, the impact of Russian on the structure of Sakha appears to have been negligible. Although this may appear surprising given the dominance of Russian as the language of education, political administration, and the widely received mass media, this can be accounted for by the fact that a number of Sakha speakers are still monolingual. Thus, Russian names for items adopted through contact with Russians have made their way into the language at the same time as the items made it into modern Sakha culture, but the grammar of rural speakers has not yet been influenced. 
The structural influence of Mongolic on Sakha has been stronger than the influence of Russian. Thus, the (somewhat archaic) use of $i k k i$ 'two' as a coordinating device was copied from Mongolic (Kałużyński [1962] 1995: 154):

$$
\begin{aligned}
& \text { Sakha: aya-m iỹe-m ikki } \\
& \text { father-Poss.1sG mother-Poss.1sG two } \\
& \text { 'my father and mother' (Uwarowskij's Erinnerungen, } \\
& \text { Mongolic: Ba:tar Dorž xoyer } \\
& \text { Baatar Dorj two } \\
& \text { 'Baatar and Dorj' (Kullmann \& Tserenpil 2001: 299) }
\end{aligned}
$$

Likewise, the extension of the Sakha Dative case to include locative as well as allative functions can be traced to Mongolic influence. Furthermore, initial Mongolic influence might have played a role in the retention of distinct Comitative and Instrumental cases in Sakha, and also in the development of the Turkic Locative case to a Partitive case (Pakendorf 2007: 120-201).

Surprisingly, in contrast to the relative paucity of lexical copies from Evenki, Evenki structural influence on Sakha has been quite strong, especially in the nominal case system of Sakha. Thus, the loss of the Turkic Genitive case, the development of an indefinite accusative meaning of the Partitive case, and possibly the retention of the Comitative-Instrumental distinction can all be traced to Evenki influence. Furthermore, the development of a Future Imperative in Sakha as well as extended uses of the possessive suffixes can be explained by Evenki contact influence (Pakendorf 2007: 95-270).

\section{The results of genetic studies}

Molecular anthropological analyses of the Sakha and neighboring populations (Pakendorf et al. 2006) confirm the hypothesis that the Sakha immigrated to their current territory from the south. Furthermore, the genetic homogeneity of the Sakha population is in good accordance with their relatively recent spread over the widespread area they inhabit nowadays, originating from a fairly small area on the middle Lena. The Y-chromosomal data show signs of a very strong and recent bottleneck of the paternal side of the population followed by an expansion; this can be dated to approximately $900 \pm 440$ years before present. A less dramatic founder event visible in the mitochondrial DNA (which is inherited solely in the maternal line) can be dated to 1,300 \pm 800 years ago (Pakendorf et al. 2006). Thus, if these expansions were caused by the same event (e.g. the migration of the Sakha ancestors to the north), this would have taken place between 700 and $1500 \mathrm{CE}$, in reasonably good agreement with the archaeological data that point to a migration north in the $13^{\text {th }}$ or $14^{\text {th }}$ century. 
There is no evidence of admixture in the paternal line between the Sakha and the indigenous inhabitants of Yakutia (Yukaghirs, Evenks, or Evens), although there is clear evidence that Sakha men married into a subgroup of western Evens. Although admixture from Evenks or Evens cannot be entirely excluded in the maternal line (due to widespread sharing of mitochondrial DNA sequence types between South Siberian Turkic-speaking groups, Sakha, Evenks, and Evens), there is no conclusive evidence for such admixture, and it cannot have been substantial.

Thus, there is no genetic evidence for a language shift of entire groups of Evenks (i.e. both men and women) to Sakha. Furthermore, there does not appear to have been large-scale intermarriage in the maternal line. This makes the finding of structural influence from the Evenki language quite intriguing, since it cannot be accounted for by substratum influence or large numbers of linguistically mixed households. An explanation might be that the group of Sakha ancestors that initially migrated to Yakutia was very small, as shown by the severely reduced genetic diversity on the Y-chromosome; this small group of immigrants may have been dependent on their indigenous neighbors in the initial period after their migration to an area with a much harsher climate than that in their South Siberian homeland (Pakendorf 2007: 317-323).

\section{Conclusions}

It is clear from the above discussion that the Sakha have been open to contact with speakers of other languages throughout a large part of their history. With a total of nearly $29 \%$ copied lexemes found in the subdatabase, Sakha can be classified as a heavily copying language (thus, Bakker \& Mous (1994: 5) suggest that "extreme borrowing never exceeds $45 \%$ ”). This large number of lexical copies is due in part to the inclusion in the Loanword Typology meaning list of lexical items pertaining to the modern world, which not unexpectedly were copied from Russian. However, Sakha has not copied only words for new items: a large number of verbs were copied from Mongolic languages, as were terms for body parts and kin. Furthermore, a very large domain of items known to have been copied from Mongolic, namely descriptive verbs, was not included in the subdatabase, so that the number of total Mongolic copies in Sakha was probably somewhat underestimated in this study; thus, Popov (1986: 8) and Rassadin (1980: 65) count between 2,000 and 2,500 words of Mongolic origin in the Sakha language. Taking the number of 6,200 lexical roots contained in Pekarskij's dictionary ([1907-1930] 1958-1959) as the basis for calculations, one would arrive at a proportion of $30-40 \%$ of Mongolic copies in Sakha.

Intriguingly, Sakha has copied only a relatively small number of items from Evenki, while it appears to have undergone noticeable structural influence from this language. This kind of structural influence is indicative of bilingualism of the Sakha ancestors in Sakha and Evenki (Winford 2005: 376f). This is a somewhat surprising finding, given that there is no conclusive evidence for large-scale Evenk genetic 
admixture in the Sakha, and given that today the Sakha language is the dominant language in Yakutia, where Evenks and Evens are at least bilingual in Sakha, if they have not shifted to this language entirely.

A last interesting finding of this study is the number of verbs copied from Mongolic: more than one quarter of the Mongolic copies detected in this study are verbs. This very high number can be explained by the fact that the Mongolic languages and Sakha are typologically similar, facilitating the transfer of verbs from one to another. Furthermore, it can be explained by the fact that the Sakha were the socially and politically subordinate group, while the Mongolic tribes were the politically dominant group during the Mongol Empire. Thus, Haugen (1950: 224) finds that Swedish and Norwegian immigrants in the USA, who constitute clear minority groups in a socially and politically dominant culture, have copied between $18 \%$ and $23 \%$ of verbs from American English.

\section{Acknowledgments}

We gratefully acknowledge financial assistance by the Max Planck Society, as well as RFBR grant No. 03-06-96033 p 2003 арктика_a to Novgorodov. Furthermore, Pakendorf thanks the inhabitants of Tabalaax for their hospitality and support, and Elizaveta Migalkina for her time and patience. 


\section{References}

Afanas'ev, P. S. \& Voronkin, M. S. \& Alekseev, M. P. 1976. Dialektologičeskij slovar' jakutskogo jazyka [Dialectological dictionary of the Sakba language]. Moscow: Izdatel'stvo 'Nauka'.

Afanas'ev, P. S. \& Xaritonov, L. N. (eds.). 1968. Russko-jakutskij slovar' [Russian-Yakut dictionary]. Moscow: Izdatel'stvo 'Sovetskaja Énciklopedija'.

Alekseev, Anatolij Nikolaevič. 1996. Drevnjaja Jakutija: Neolit i epoxa bronzy [Ancient Yakutia: The Iron Age and the Medieval Epoch]. Novosibirsk: Izdatel'stvo Instituta Arxeologii i Etnografii SO RAN.

Anikin, Aleksandr Evgen'evič. 2003. Ėtimologičeskij slovar' russkix zaimstvovanijax v jazykax Sibiri [Etymological dictionary of the Russian borrowings in the languages of Siberia]. Novosibirsk: 'Nauka'.

Antonov, N.K. 1971. Materialy po istoričeskoj leksike jakutskogo jazyka [Materials on the bistorical lexicon of Yakut]. Yakutsk: Jakutskoe knižnoe izdatel'stvo.

Bakker, Peter \& Mous, Maarten. 1994. Introduction. In Bakker, Peter \& Mous, Maarten (eds.), Mixed Languages: 15 Case Studies in Language Intertwining. Amsterdam: IFOTT.

Böhtlingk, Otto (ed.). 1964 [1851]. Uwarowskij's Erinnerungen. In Über die Sprache der Jakuten: Grammatik, Text und Wörterbuch [On the language of the Jakuts: Grammar, text and dictionary] (Indiana University Publications, Uralic and Altaic Series 35). The Hague: Mouton \& Co.

Cincius, Vera Ivanovna (ed.). 1975. Sravnitel'nyj slovar' tunguso-man'čžurskix jazykov: Materialy $k$ étimologičeskomu slovarju [Comparative dictionary of the Tungusic languages: Materials for an etymological dictionary]. Vol. 1: A-N. Leningrad: Izdatel'stvo 'Nauka', Leningradskoe otdelenie.

Cincius, Vera Ivanovna (ed.). 1977. Sravnitel'nyj slovar' tunguso-man'čžurskix jazykov: Materialy $k$ ètimologičeskomu slovarju [Comparative dictionary of the Tungusic languages: Materials for an etymological dictionary]. Vol. 2: O-E். Leningrad: Izdatel'stvo 'Nauka', Leningradskoe otdelenie.

Dolgix, Boris Osipovič. 1960. Rodovoj i plemennoj sostav narodov Sibiri v XVII veke [The tribal composition of the peoples of Siberia in the $17^{\text {th }}$ century]. Moscow: Izdatel'stvo Akademii Nauk SSSR.

ESTJ. Etimologičeskij slovar' tjurkskix jazykov [Etymological dictionary of the Turkic languages].

ESTJ 1974. Sevortjan, Ėrvand Vladimirovič. Obščetjurkskie i mežtjurkskie osnovy na glasnye [Common Turkic and Middle Turkic roots beginning in vowels]. Moscow: Izdatel'stvo 'Nauka'.

ESTJ 1978. Sevortjan, Ėrvand Vladimirovič. Ob̌̌četjurkskie i mežtjurkskie osnovy na bukvu "B” [Common Turkic and Middle Turkic roots beginning with the letter "B"]. Moscow: Izdatel'stvo 'Nauka'. 
ESTJ 1980. Sevortjan, Ėrvand Vladimirovič. Obščetjurkskie i mežtjurkskie osnovy na bukvy "V”, "G", $i$ " $D$ " [Common Turkic and Middle Turkic roots beginning with the letters " $V$ ", "G", and “D”. Moscow: Izdatel'stvo 'Nauka'.

ESTJ 1989. Levitskaja, L. S. (ed.). Obščetjurkskie i mežtjurkskie osnovy na bukvy “Dz”, “Ž”, i "J" [Common Turkic and Middle Turkic roots beginning with the letters "D3", "Ž", and “J”]. Moscow: Izdatel'stvo 'Nauka'.

ESTJ 1997. Levitskaja, L.S. \& Dybo, A.V. \& Rassadin, V.I. Obščetjurkskie i mežtjurkskie leksičeskie osnovy na bukvy " $K$ ", "Q” [Common Turkic and Middle Turkic lexical roots beginning with the letters “ $K$ ”, “ $Q$ ”]. Moscow: 'Jazyki Russkoj Kul'tury'.

ESTJ 2000. Blagova, G. F. (ed.). Ob̌̌četjurkskie i mežtjurkskie leksičeskie osnovy na bukvu " $K$ ” [Common Turkic and Middle Turkic lexical roots beginning with the letter " $K$ "]. Moscow: Izdatel'stvo 'Indrik'.

ESTJ 2003. Dybo, A. V. (ed.). Ob̌̌četjurkskie i mežtjurkskie leksičeskie osnovy na bukvy L, $M$, $N, P, S$ [Common Turkic and Middle Turkic lexical roots beginning with the letters $L, M$, $N, P, S]$. Moscow: Izdatel'skaja firma 'Vostočnaja literatura' RAN.

Federal'naja služba gosudarstvennoj statistiki. 2004. Nacional'nyj sostav i vladenie jazykami, graždanstvo: Itogi vserossijskoj perepisi naselenija 2002 goda [Composition of nationalities and knowledge of languages, citizenship: Results of the All-Russian Population Census of 2002]. Moscow: IIC 'Statistika Rossii'.

Forsyth, James. 1992. A History of the Peoples of Siberia: Russia's North Asian Colony 15811990. Cambridge: Cambridge University Press.

Gogolev, Anatolij Ignat'evič. 1993. Jakuty: Problemy ètnogeneza i formirovanija kul'tury [The Yakuts: Problems of their ethnogenesis and the formation of their culture]. Yakutsk: Izdatel'stvo JaGU.

Haugen, Einar. 1950. The Analysis of Linguistic Borrowing. Language 26(2):210-231.

Janhunen, Juha. 1998. Ethnicity and language in prehistoric Northeast Asia. In Blench, Roger \& Spriggs, Matthew (eds.), Archaeology and Language II: Correlating archaeological and linguistic bypotheses, 195-208. London/New York: Routledge.

Johanson, Lars. 1998. The history of Turkic. In Johanson, Lars \& Csató, Éva Ágnes (eds.), The Turkic Languages, 81-125. London/New York: Routledge.

Kałużyński, Stanisław. 1995. IACUTICA: Prace jakutoznawcze [IACUTICA: Yakutological studies]. Warsaw: Wydawnictwo Akademickie DIALOG.

Kałużyński, Stanisław. 1995 [1962]. Mongolische Elemente in der jakutischen Sprache [Mongolian elements in the Jakut language]. Reprinted as part of Kałużyński, Stanisław (1995). 's-Gravenhage: Mouton \& Co. Original edn. 1962. Warsaw: Państwowe Wydawnictwo Naukowe.

Kecskeméti, István (comp.). 1971. Martti Räsänen: Versuch eines etymologischen Wörterbuchs der Türksprachen [Martti Räsänen: Attempt at an etymological dictionary of the Turkic languages]. Vol. 2: Wortregister. Helsinki: Suomalais-Ugrilainen Seura. 
Konstantinov, Ivan Vasil'evič. 2003 [1975]. Proisxoždenie jakutskogo naroda i ego kul'tury [The origins of the Yakut people and their culture]. Yakutsk: Akademija nauk Respubliki Saxa (Jakutija), Institut gumanitarnyx issledovanij.

Kullmann, Rita \& Tserenpil, D. 2001. Mongolian Grammar. Ulaanbaatar: Institute of Language and Literature, Academy of Sciences.

Lessing, Ferdinand D. (ed.). 1995. Mongolian-English Dictionary. Third reprinting with minor type-corrections. Bloomington, Indiana: The Mongolia Society, Inc.

Maslova, Elena Sergeevna \& Vaxtin, Nikolaj Borisovič. 1996. The Far North-East of Russia. In Wurm, Stephen A. \& Mühlhäusler, Peter \& Tryon, Darrell T. (eds.), Atlas of Languages of Intercultural Communication in the Pacific, Asia, and the Americas, 9991001. Berlin/New York: Mouton de Gruyter.

Okladnikov, A. P. 1955. Istorija Jakutskoj ASSR [The History of the Yakut ASSR]. Vol 1: Jakutija do prisoedinenija $\mathrm{k}$ russkomu gosudarstvu [Yakutia before Its Incorporation into the Russian State]. Moscow, Leningrad: Izdatel'stvo Akademii Nauk SSSR.

Pakendorf, Brigitte. 2007. Contact in the prehistory of the Sakba (Yakuts): Linguistic and genetic perspectives. (LOT Dissertation series 170). Utrecht: LOT.

Pakendorf, Brigitte \& Novgorodov, Innokentij N. \& Osakovskij, Vladimir L. \& Danilova, Al'bina P. \& Protod'jakonov, Artur P. \& Stoneking, Mark. 2006. Investigating the effects of prehistoric migrations in Siberia: Genetic variation and the origins of Yakuts. Human Genetics 120(3):334-353.

Pekarskij, Ėdvard Karlovič. 1958-1959 [1907-1930]. Slovar' jakutskogo jazyka [Dictionary of Yakut]. Facsimile reprint of the $1^{\text {st }}$ edn. Otdelenie literatury i jazyka Akademii Nauk SSSR, Jakutskij filial Akademii Nauk SSSR.

Popov, Gavriil Vasil'evič. 1986. Slova 'neizvestnogo proisxoždenija' jakutskogo jazyka: Sravnitel'no-istoričeskoe issledovanie [The words of 'unkown origin' in Yakut: A comparative-bistorical study]. Yakutsk: Jakutskoe knižnoe izdatel'stvo.

Räsänen, Martti. 1969. Versuch eines etymologischen Wörterbucbs der Türksprachen [Attempt at an etymological dictionary of the Turkic languages]. Helsinki: Suomalais-Ugrilainen Seura.

Rassadin, Valentin Ivanovič. 1980. Mongolo-burjatskie zaimstvovanija v sibirskix tjurkskix jazykax [Mongolo-Buryat borrowings in the Turkic languages of Siberia]. Moscow: 'Nauka'.

Romanova, Agnija Vasil'evna \& Myreeva, Anna Nikolaevna \& Baraškov, Petr Petrovič. 1975. Vzaimovlijanie evenkijskogo i jakutskogo jazykov [Mutual Influence of the Evenk and Yakut Languages]. Leningrad: Izdatel'stvo 'Nauka'. Leningradskoe Otdelenie.

Safronov, F. G. (ed.). 2000. Enciklopedija Jakutii [Jakut encyclopedia]. Moscow: OOO 'Jakutskaja Ėnciklopedija'.

Ščrbak, Aleksandr Mixajlovič. 1994. Vvedenie v sravnitel'noe izučenie tjurkskix jazykov [Introduction to comparative Turkic studies]. St-Petersburg: 'Nauka'.

Schönig, Claus. 1997. A new attempt to classify the Turkic languages 1. Turkic Languages 1:117-133. 
Seroševskij, Vaclav Leopol'dovič. 1993 [1896]. Jakuty [The Yakuts]. Moscow: Rossijskaja političeskaja enciklopedija (ROSSPEN).

Širobokova, Natal'ja Nikolaevna. 1977. Ob otnošenii jakutskogo jazyka $\mathrm{k}$ jazykam drevnetjurkskix pamjatnikov [On the relationship of Yakut to the language of the Old Turkic remains]. In Ubrjatova, Elizaveta Ivanovna (ed.), Issledovanija po jazykam narodov Sibiri: Sbornik naučnyx trudov, 108-116. Novosibirsk: Sibirskoe Otdelenie AN SSSR. Institut Istorii, Filologii i Filosofii.

Slepcov, P. A. (ed.). 1972. Jakutsko-russkij slovar' [Yakut-Russian dictionary]. Moscow: Izdatel'stvo 'Sovetskaja Ėnciklopedija'.

Slepcov, P. A. (ed.). 2004. Tolkovyj slovar' jakutskogo jazyka [Explanatory dictionary of Yakut]. Tom 1: Bukva A [Vol. 1: Letter A]. Novosibirsk: 'Nauka'.

Slepcov, P. A. (ed.). 2005. Tolkovyj slovar' jakutskogo jazyka [Explanatory dictionary of Yakut]. Tom 2: Bukva B [Vol. 2: Letter B]. Novosibirsk: 'Nauka'.

Stachowski, Marek. 1995. Jakutisch und dolganisch mas ‘Baum' [Jakut and Dolgan mas 'tree']. Central Asiatic Journal 39(2):270-274.

Tenišev, E. R. (ed.). 2001. Sravnitel'no-istoričeskaja grammatika tjurkskix jazykov: Leksika [Comparative-historical grammar of the Turkic languages: Lexicon]. $2^{\text {nd }}$ edn. Moscow: 'Nauka'.

Tugolukov, Vladilen Aleksandrovič. 1985. Tungusy (evenki i èveny) Srednej i Zapadnoj Sibiri [The Tungus (Evenks and Evens) of Central and Western Siberia]. Moscow: Izdatel'stvo 'Nauka'.

Voronkin, M. S. \& Alekseev, M. P. \& Vasil'ev, Ju. I. 1995. Dialektologičeskij slovar' jazyka Saxa (dopolnitel'nyj tom) [Dialectological dictionary of the Sakha language (supplementary volume)]. Novosibirsk: VO 'Nauka'.

Voronkin, Mixail Spiridonovič. 1999. Dialektnaja sistema jazyka Saxa [The dialect system of the Sakba language]. Novosibirsk: 'Nauka'. Sibirskaja izdatel'skafja firma RAN.

Weiers, Michael. 1986. Zur Herausbildung und Entwicklung mongolischer Sprachen: Ein Überblick [On the formation and development of Mongolian languages: An overview]. In Weiers, Michael (ed.), Die Mongolen: Beiträge zu ibrer Geschichte und Kultur, 29-69. Darmstadt: Wissenschaftliche Buchgesellschaft.

Winford, Donald. 2005. Contact-induced changes: Classification and processes. Diachronica 22(2):373-427.

Wurm, Stephen A. 1996. Siberia: 1650-1950 ethnic and linguistic changes. In Wurm, Stephen A. \& Mühlhäusler, Peter \& Tryon, Darrell T. (eds.), Atlas of Languages of Intercultural Communication in the Pacific, Asia, and the Americas, 969-974. Berlin/New York: Mouton de Gruyter. 


\section{Appendix of lexical copies}

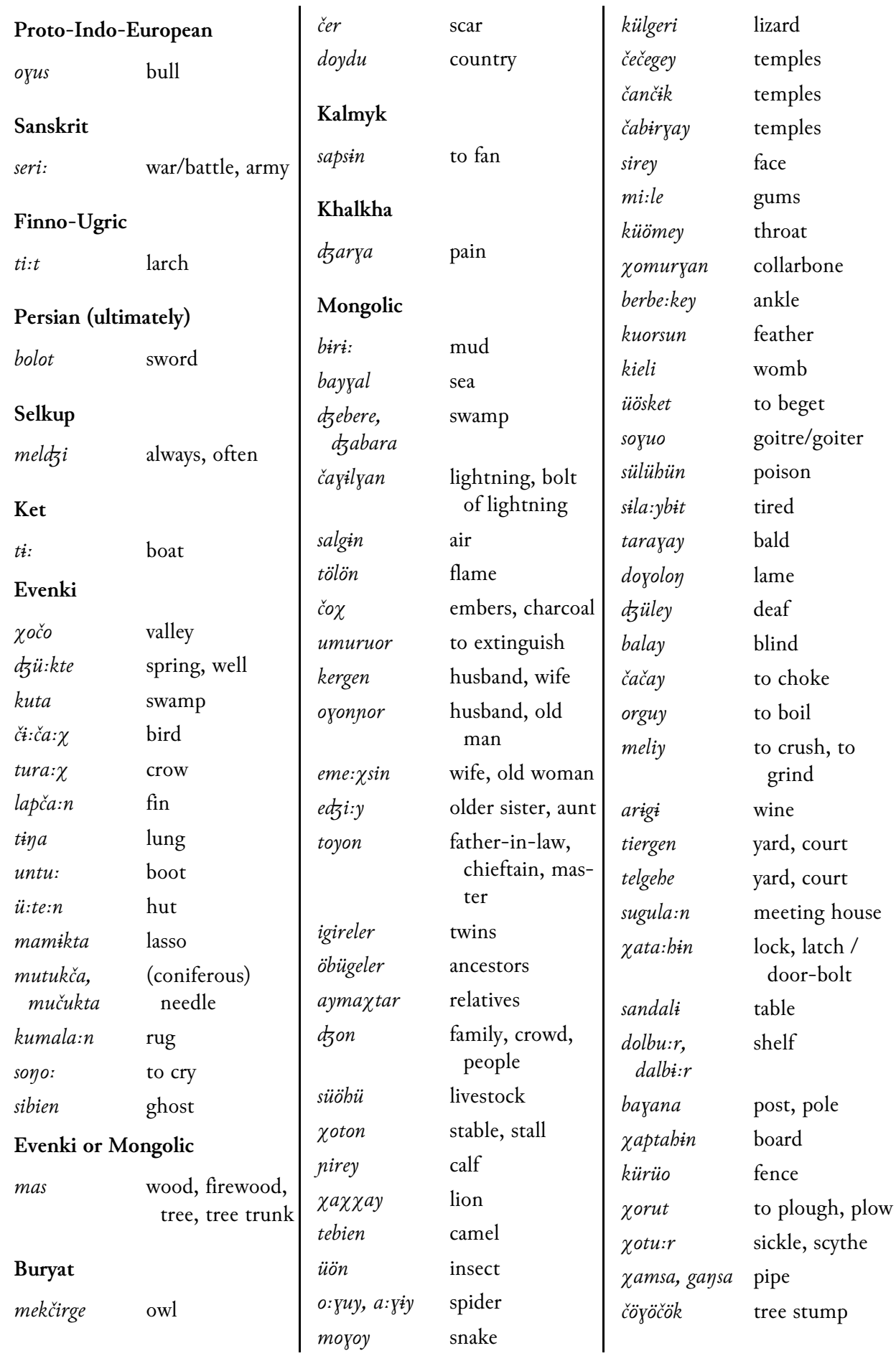




\begin{tabular}{|c|c|c|c|c|c|}
\hline ača: $\chi$ & forked branch & $s \ddot{p}$ & enough & kü:büle: & rape \\
\hline sime & sap & kem & time & $a p$ & magic \\
\hline üle & work & eder & young & xomubun, & magic \\
\hline tokurut & to bend & xoyut & late & zobubun & \\
\hline kelgiy & to tie & tietey & to hurry & Russian & \\
\hline süge & axe/ax & belem & ready & Kussian & \\
\hline ültürüt & to break & na:r & always, often & $b i: l$ & dust \\
\hline tenit & to stretch & $d\}^{a} l$ & year, season & muora & sea \\
\hline telget & to spread out & ayility & to smell & akiya:n & ocean \\
\hline xarba: & to sweep & $d e \chi s i$ & smooth & xoluodzas & spring, well \\
\hline sep & tool & sohuybut & surprised, aston- & bu:rya & storm \\
\hline$\check{c} \ddot{u}: \check{c} \check{c} \ddot{u}$ & chisel & & ished & pa:r & st \\
\hline ergiy & to turn around & dzol & good luck & $i s p i$ & \\
\hline eriy & to twist & sana: & grief, idea & siba:yba & \\
\hline saxsiy & to shake & kemsin & to regret, be & bira:t & $\begin{array}{l}\text { younger brother, } \\
\text { nephew, }\end{array}$ \\
\hline čoxčoy & to crouch & & anger & & cousin \\
\hline xaltariy & to slide, to slip & eren & anger & ma:čaxa ĩye & stepmother \\
\hline dabay & to go up & eren & pe & ogdo:bo & widow(er) \\
\hline buryaldzi & yoke & buruy & fault, crime & bostu:k & herdsman \\
\hline siarya & sledge/sled & & beautiful & sibinne & pig \\
\hline oyočo & boat & & to & čosku & pig \\
\hline mal & thing & & & bötü:k & cock/rooster \\
\hline örübüy & to rescue & & uess & ku:russa & hen \\
\hline abira: & to rescue & stitax & cause & čopu:ska & chicken \\
\hline aldzan & to damage & $s a: t$ & ot & 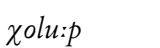 & dove \\
\hline dzadayi & poor & $t a$ & to & xoruoluk & rabbit \\
\hline keččegey & stingy, greedy & & to try & kuoska & cat \\
\hline tölö: & to pay & & mai & bìla $\dot{i}$ & flea \\
\hline čepčeki & cheap, light, easy & sibiginey & to whisper & taraka:n & cockroach \\
\hline tobox & remains & Meldzes & & kuma:r & mosquito \\
\hline хотиy & to gather & Suruy & & čierbe & worm \\
\hline xolbo: & to join & Omuk & pec & buobura & beaver \\
\hline oroy & top & Salc & le/gor & matka & womb \\
\hline bödöy & big & doyor & & temperatura & fever \\
\hline bïčika:n & small & & $\mathrm{P}$ & bira:s & physician \\
\hline zaptayay & flat & čuguy & to retreat & $d z a: t$ & poison \\
\hline köxö & hook & xarabil & guard & iha:rila: & to roast, to fry \\
\hline tögürük & round & küögü & fishhook & čugu:n & pot \\
\hline ulariy & to change & berehit & witness & köstörü:le & pot \\
\hline elbex & hany & $\begin{array}{l}\text { kerebit } \\
\text { andayar }\end{array}$ & $\begin{array}{l}\text { witness } \\
\text { oath }\end{array}$ & ča:nnìk & kettle \\
\hline
\end{tabular}




\begin{tabular}{|c|c|c|c|c|c|}
\hline 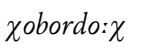 & pan & tü:ppüle & shoe & kira:bìl & rake \\
\hline bülü:de & dish & bačì:nka & shoe & sieme & seed \\
\hline terielke & plate & sappiki & boot & ku:mna & threshing-floor \\
\hline miske & bowl & sele:ppe & hat, cap & seliebiney & wheat \\
\hline ta:s & bowl & siep & pocket & dzebimien, & barley \\
\hline kupsu:n & jug/pitcher & bula:pka & pin & nečimien & \\
\hline ča:skí & cup & külü:ske & ring & (archaic) & \\
\hline bülü:be & saucer & xoruoyka & necklace, bead & oruos & rye \\
\hline luoska & spoon & bila:t & headband / & ebies & oats \\
\hline biri:ppe & knife, razor & & headdress, & kukuruza & maize/corn \\
\hline bi:lke & fork & & $\begin{array}{l}\text { handkerchief, } \\
\text { rag }\end{array}$ & $\begin{array}{l}\text { iri:s } \\
\text { sibekki }\end{array}$ & $\begin{array}{l}\text { rice } \\
\text { flower }\end{array}$ \\
\hline sipsi: & tongs & suokka & brush & $l u: k$ & oak \\
\hline ebiet & lunch & ma:s & ointment & tabax & tobacco \\
\hline kiliep & bread & mi:la & soap & siap & chain \\
\hline mehiv & $\begin{array}{l}\text { oougn } \\
\text { to knead }\end{array}$ & sierkele & mirror & mi:nnik & broom \\
\hline mielinse & mill & bala:kka & tent & sibinne:s & lead \\
\hline zalbabi & sausage & olbuor & yard, court & östüöküle & glass \\
\hline sasiska & sausage & kulu:p & meeting house & korzina & basket \\
\hline xortuoska & potato & xoluoda & doorpost & kira:ska & paint \\
\hline zortuopuy & potato & külü:s & lock, padlock & buru:s & whetstone \\
\hline eriexe & nut & muosta & floor & teliege & cart, wagon \\
\hline bieres & pepper & kömü̈lüök & fireplace & kölüöhe & wheel \\
\hline müöt & honey & turba & chimney & xara:bíl & ship \\
\hline sa: $\chi a r$ & sugar & kirilies & ladder & borokuot & ship \\
\hline sì:r & cheese & ustu:l & chair & uru:l & rudder \\
\hline $\begin{array}{l}\text { pribe } \\
\text { hirg.og }\end{array}$ & beer & ostuol & table & mačta & mast \\
\hline bira:ga & (1) & la:mpa & lamp, torch & ba:ris & sail \\
\hline solko & silk & bana:r & lamp, torch & dza:kir & anchor \\
\hline bo:ldzox & felt & č̈̈meči & candle & port & port \\
\hline bíla:ččíya & (womans) dress & xoru:da & trough & maniat & coin \\
\hline$\dot{i} r b a: \chi \dot{t}$ & (womans) dress, & ktrt:sa & roof & suot & bill \\
\hline & shirt & $\begin{array}{l}\text { Xoruobuya } \\
\text { ostuolba }\end{array}$ & post, pole & noluok & $\begin{array}{l}\operatorname{tax} \\
\text { market }\end{array}$ \\
\hline boituo & coat & kirpi:čče & brick & mayabi:n & shop/store \\
\hline$d z u: p p a$ & skirt & ispieske & mortar & la:ppi & shop/store \\
\hline ista:n & trousers & ba:binay & farmer & siana & price \\
\hline bürü:ke & trousers & ba:bina & field & kiries & cross \\
\hline čulku, čukku & sock, stocking & oyuruot & garden & nu:l & zero \\
\hline naski & sock, stocking & $\chi a n a: b a$ & ditch & tibbi:nča & a thousand \\
\hline
\end{tabular}


524 Brigitte Pakendorf and Innokentij N. Novgorodov

\begin{tabular}{|c|c|c|c|c|c|}
\hline ire:t & part & kirieppes & fortress & ministr & minister \\
\hline ča:s (1) & part & ata:ka & attack & milisssiye & police \\
\hline pa:ra & pair & bilienney & captive, prisoner & $b \dot{z}: b a r$ & election \\
\hline birieme & time & zapka:n & trap & a:diris & address \\
\hline kuru:k & always, often & ča:rka:n & trap & nüömer & number, license \\
\hline ča:s (2) & hour & sokuon & law & & plate \\
\hline$\check{c} a b \dot{t}$ & clock & su:t & court & u:lussa & street \\
\hline nediele & week & sudzuya & judge & počta & post/mail \\
\hline benidiennik & Monday & istara: $p$ & fine & ma:rka & postage stamp \\
\hline optuorunnuk & Tuesday & siertibe & sacrifice & atkritka & postcard \\
\hline serede & Wednesday & iray & heaven & bank & bank (financial \\
\hline čeppier & Thursday & $a: t$ & hell & & os \\
\hline be:tinse & Friday & ara:dziya & radio & kíra:n & tap/taucet \\
\hline subuota & Saturday & telebi:zer & television & rakovina & \\
\hline birasti: gin & to forgive & tölüpüön & telephone & tualet & toilet \\
\hline kirabiabay & beautiful & belasiped & bicycle & matara:s & mattress \\
\hline mu:daray & wise & matassikitl & motorcycle & $\begin{array}{l}\text { kensierbe } \\
\text { ba:nkata }\end{array}$ & $\operatorname{tin} / \mathrm{can}$ \\
\hline uču:tal & teacher & massit:na & car, machine & bi:nte & screw \\
\hline oskuola & school & avtobus & bus & etibierke & screwdriver \\
\hline čuolkay & clear & buoyas & train & bitit:lka & bottle \\
\hline sial & intention & sömölüöt & airplane & kempiet & candy/sweets \\
\hline kuma:yi & paper & dzarapila:n & airplane & plasma:s & plastic \\
\hline uru:čka & pen & batareya & battery & buomba & bomb \\
\hline kinige & book & motuor & motor & böppürüöske & cigarette \\
\hline baraba:n & drum & neft & petroleum & rabiat & newspaper \\
\hline kuorat & town & bali:ba & hospital & zalanda:r & calendar \\
\hline böbüülek & village & siestere & nurse & ki:ne & film/movie \\
\hline deriebine & village & ukuol & injection & $m u z i k a$ & music \\
\hline kirani:ssa & boundary & $a \check{c} \dot{i} k \dot{i}$ & spectacles/glasses & $\check{c} e y, \check{c} a y$ & tea \\
\hline mebeyde: & to prevent & pravitelstva & government & kofe & coffee \\
\hline salla:t & soldier & prezident & president & & \\
\hline
\end{tabular}

